\title{
Trace Element Zinc, a Nature's Gift to Fight Unprecedented Global Pandemic COVID-19
}

\author{
Priyanka Sharma ${ }^{1}$ (D) Prasanna Kumar Reddy ${ }^{1} \cdot$ Bhuvnesh Kumar $^{1}$
}

Received: 18 September 2020 / Accepted: 28 October 2020 / Published online: 10 November 2020

(C) Springer Science+Business Media, LLC, part of Springer Nature 2020

\begin{abstract}
With the advent of twenty-first century, we are in cruel grip of a pandemic caused by severe acute respiratory syndrome coronavirus-2 (SARS-CoV-2), the associated illness being called as COVID-19. Since its outbreak in December 2019 in Wuhan, China, there are no medicines to cure the disease till date. Based on their experience, scientists say that developing a coronavirus vaccine could take at least a year. There are many steps in place before the vaccine comes for the distribution like its safety and cost-effectiveness, especially for the developing countries. In this scenario, the only way to prevent the disease is by following certain safety guidelines and to boost up the body's immune system. Zinc, a crucial trace element involved in several biological and metabolic processes, has been found to play a pivotal role in promoting and appropriately regulating the host defense mechanisms against viral infections. Zinc is naturally present in some foods, fortified in others and also available as dietary supplement. The current RDA (Recommended Daily Allowance) of zinc is 12 and $10 \mathrm{mg}$ for males and females respectively. Zinc is the second most common trace mineral after iron in the cell. It is present in all organs and tissues in the body as it forms catalytic component of all 6 classes of enzymes encompassing almost 2000 enzymes in the body. Zinc is biologically essential for cellular processes, including growth and development, as well as DNA synthesis and RNA transcription. Zinc deficiency results in a number of metabolic changes besides a compromised immune system. In this review, the role of zinc in regulating the host defense and viral replication is being discussed with the main focus on COVID-19.
\end{abstract}

Keyword COVID-19 $\cdot$ Host defense $\cdot$ SARS $\cdot$ Trace elements $\cdot$ Zinc

\section{Introduction}

According to World Health Organisation (WHO), coronaviruses are a large family of viruses (Fig. 1) [1,2]. In humans, coronaviruses cause respiratory infections ranging from the common cold to more severe diseases such as Middle East respiratory syndrome (MERS) and severe acute respiratory syndrome (SARS). The most recently discovered coronavirus causes coronavirus disease named as COVID-19. The Coronaviridae Study Group (CSG) of the International Committee on Taxonomy of Viruses (ICTV) has found the virus responsible for this disease to be a prototype of human and bat SARS coronaviruses (SARS-CoVs) of the species severe acute respiratory syndrome-related coronavirus, and

Priyanka Sharma

ps24july@gmail.com

1 Defence Institute of Physiology and Allied Sciences, Lucknow Road, Timarpur, Delhi 110054, India designates it as SARS-CoV-2 [3]. The electron microscopic image of coronaviruses resembles that of a crown and hence the viruses are prefixed with the term "Corona" [3]. Corona means crown in Latin language.

SARS-CoV-2 mainly infects cells of the alveoli, the smallest passageway in the respiratory system. Walls/linings of alveoli are made up of single layer of two types of cells (type I and II pneumocytes). Type I pneumocytes are squamous epithelial cells and make $95 \%$ of the surface area of each alveolus. They are responsible for the exchange of oxygen and carbon dioxide. Type II pneumocytes are cuboidal shape and are responsible for repairing damage to the alveolar lining and also secrete surfactant. This surfactant coats the inner surface of the alveolus and helps reduce surface tension. The surfactant maintains the shape of each alveolus during breathing process. There are also many alveolar macrophages in the alveoli. These are mononuclear immune cells that phagocytize inhaled debris including dead cells and bacteria. Besides, they also help in presenting antigen to the adaptive immune cells. In cases of SARS-CoV-2 infection, alveoli get inflamed primarily; the condition is also referred to as pneumonia and is 
Fig. 1 Taxonomic classification of coronavirus

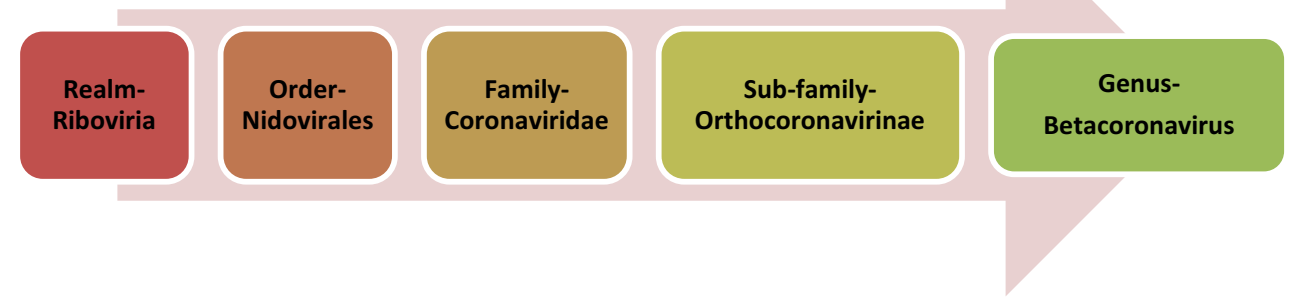

associated with high mortality rate [4, 5]. Characteristic symptoms include fever, chest pain, dry cough and difficulty in breathing. For the last six months across the world, several measures like complete to partial lockdowns have been taken by the governments and Head of States to contain the spread of disease but now considering the socio-economic conditions, the unlock process has been started. With the continuous surge in the number of COVID-19 cases the individuals, especially young people with no comorbidities are exposed to herd immunity. Immunity is a broad and complex term in itself but it is a fact that when pathogenic organisms like virus attack human body, we turn to our immune system to fight such an array of threats. The timeline of the production and distribution of vaccine seems long; it is better to make our immune system strong because if the immune system functions optimally, the other systems can concentrate on their respective functions. It has been reported that in case of dysfunctional immune system, even the metabolic functions are disturbed. The intestinal epithelium starts performing some of the missing immune functions like secretion of $\operatorname{Ig} \mathrm{A}$ (immunoglobin A) at the expense of its own metabolic activity [6]. The micronutrient zinc ( $\mathrm{Zn})$ is important for safeguarding immune cells of both the innate and adaptive immunity. An imbalance in $\mathrm{Zn}$ homeostasis causes impaired immune function, leading to compromised host defense and an increased risk of contracting diseases. This review will focus on the potential role of $\mathrm{Zn}$ in boosting immunity and also its role in fighting against COVID-19 pandemic.

\section{Role of Zinc in Body's Physiological Functions}

In 1869, Raulin for the first time recognized the role of $\mathrm{Zn}$ in biological systems. Raulin was a student of Louis Pasteur who worked on Aspergillus niger, a fungus that caused black mold in some agricultural crops. He reported that $\mathrm{Zn}$ was required for the growth of the fungus [7]. However, the significance of $\mathrm{Zn}$ remained questionable until 1961 when a study was published which described that $\mathrm{Zn}$ deficiency may have caused growth retardation and hypogonadism in Iranian males [8]. Since then myriad research was conducted that proved beneficial therapeutic response of $\mathrm{Zn}$ supplementation in diarrhea of children, chronic hepatitis $\mathrm{C}$, shigellosis, leprosy, tuberculosis, pneumonia, acute lower respiratory tract infection, common cold, and leishmaniasis [9]. The primary source of $\mathrm{Zn}$ is a diet rich in fish, eggs, shellfish (especially oysters), and red meat for non-vegetarians [10] and grains, peanuts, fruits, dairy products, and green leafy vegetables for vegetarians [11].

$\mathrm{Zn}$ is the second most common trace mineral after iron in the cells. It is present in all body tissues and fluids (total body $\mathrm{Zn}$ content is approximately $2 \mathrm{~g}$ ). Figure 2 summarizes the tissue distribution of $\mathrm{Zn}$ in the body. Approximately $60 \% \mathrm{Zn}$ is stored in skeletal muscle, $30 \%$ in bone and $5 \%$ in liver and skin and the remainder distributed in other tissues that include the brain, kidneys, pancreas and heart [12]. Only about $0.1 \%$ of this metal ion circulates in plasma and plays a major role of maintaining homeostasis in the body $[13,14]$. Excess zinc is primarily released through gastrointestinal secretion and endogenous excretion, with minor loss through urinary excretion.

\section{Zinc Transporters and Functions of Zinc}

In mammalian cells, intracellular $\mathrm{Zn}$ exists in two forms:
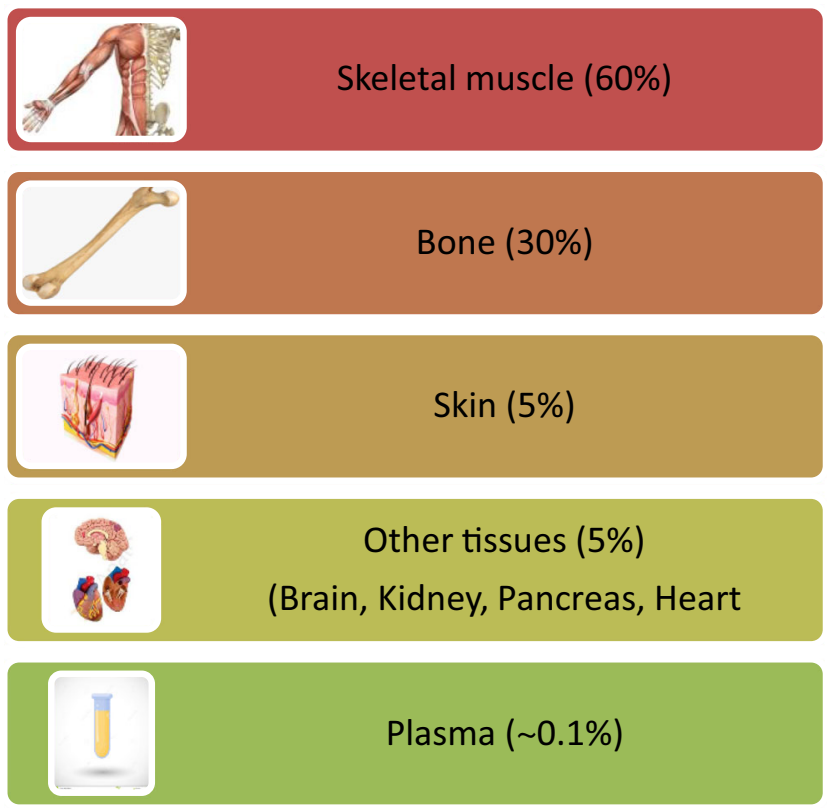

Fig. 2 Distribution of zinc in human body 
Fig. 3 Functions of zinc in human body

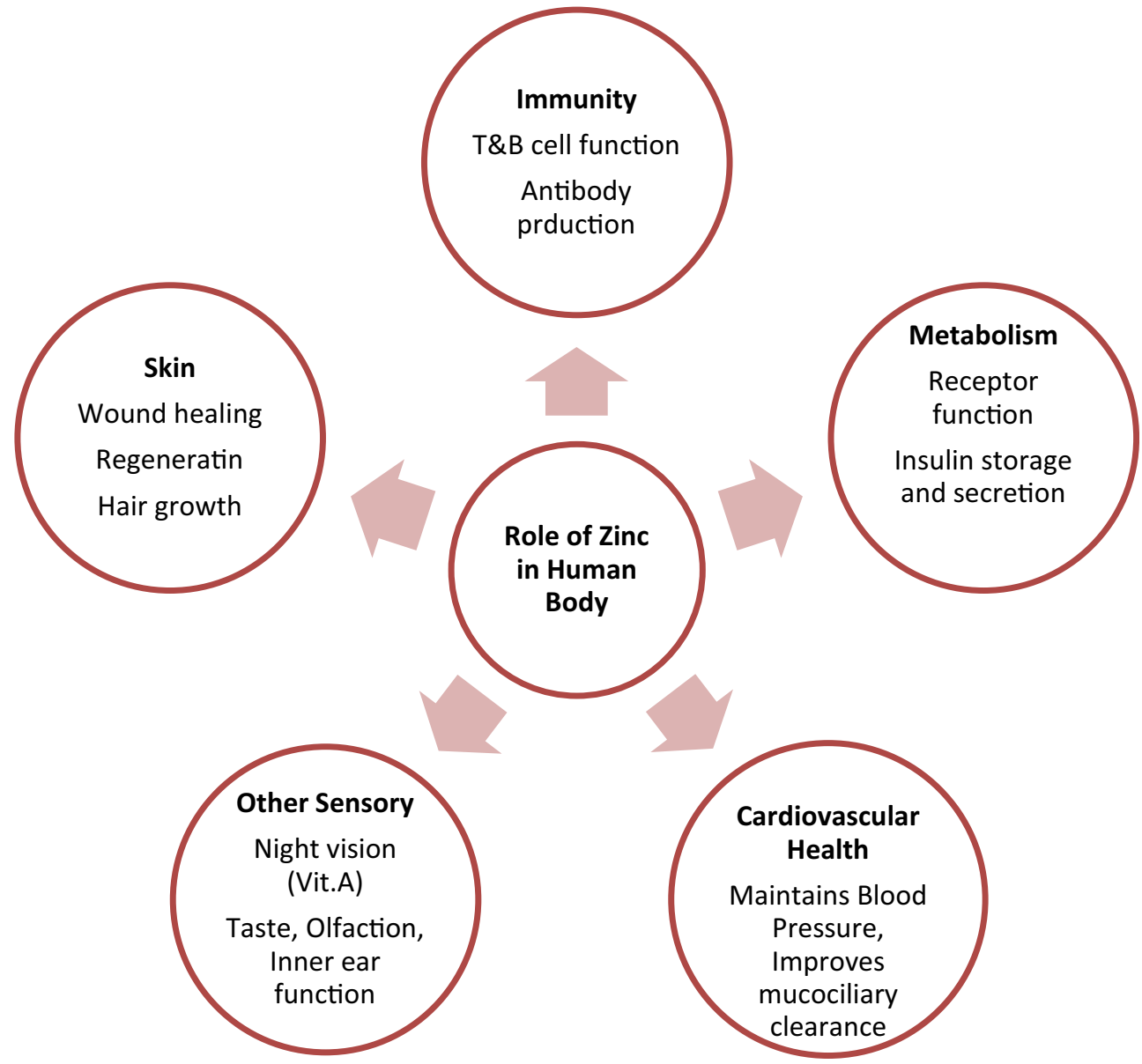

(i) Bound form (tightly bound to metalloenzymes, metalloproteins, and nucleoproteins and loosely bound to various proteins and amino acid ligands) [15].

(ii) Unbound form as free $\mathrm{Zn}^{2+}$ ions are present at very low concentrations which functions in cell control and cellto-cell communication [15]. Therefore, strict regulation of the intracellular level of $\mathrm{Zn}$ is required for the maintenance of physiological conditions. Both intracellular and compartmental $\mathrm{Zn}$ homeostasis is tightly controlled by the $\mathrm{ZnT}$ and ZIP families of transporter proteins. $\mathrm{Zn}$ transporter proteins or simply $\mathrm{Zn}$ transporters, are membrane transport proteins of the solute carrier family which control the membrane transport of $\mathrm{Zn}$ and regulate its intracellular and cytoplasmic concentrations. They include two major groups: (1) the $\mathrm{Zn}$ transporter ( $\mathrm{ZnT}$ ) or solute carrier 30 (SLC30) families, which control the efflux of $\mathrm{Zn}$ from the cytoplasm out of the cell and from the cytoplasm into vesicles. The family consists 10 subtypes (ZnT1-10) and (2) the Zn importer, Zrt- and Irt-like protein (ZIP), or solute carrier 39A (SLC39A) family, which controls the influx of zinc into the cytoplasm from outside the cell and from vesicles. The family consists of 14 subtypes (ZIP1-14) [16]. These crucial transporters are responsible for stabilizing intracellular $\mathrm{Zn}$ within cells. These transporters are either tissue specific or universally expressed in tissues depending on transporter subtype. Deregulation or malfunction of these transporters lead to various diseases. $\mathrm{Zn}$ is a structural constituent of about $750 \mathrm{Zn}$-finger transcription factors [17] enabling gene transcription, and is a catalytic component of all 6 classes of enzymes (hydrolase, transferase, oxido-reductase, ligase, lyase, and isomerase) [18] that encompasses almost 2000 enzymes. Hence, $\mathrm{Zn}$ is biologically essential for cellular processes, including growth and development, as well as DNA synthesis and RNA transcription [19]. Globally, $\mathrm{Zn}$ deficiency is estimated to range from $\sim 17$ to $20 \%$ [20,21] with the vast majority occurring in developing countries of Africa and Asia. In high-income nations, $\mathrm{Zn}$ deficiency occurs mostly in the elderly, vegetarians, and in the individuals with chronic disease such as liver cirrhosis [22] or inflammatory bowel disease [23]. Notably, Zn deficiency results in a compromised immune system, as evidenced by thymic atrophy, lymphopenia, and defective lymphocyte responses in animal studies [24].

The symptoms of a moderate deficiency of $\mathrm{Zn}$ include growth retardation, male hypogonadism in adolescents, rough 
Table 1 Structure of $\mathrm{Zn}$-ionophores

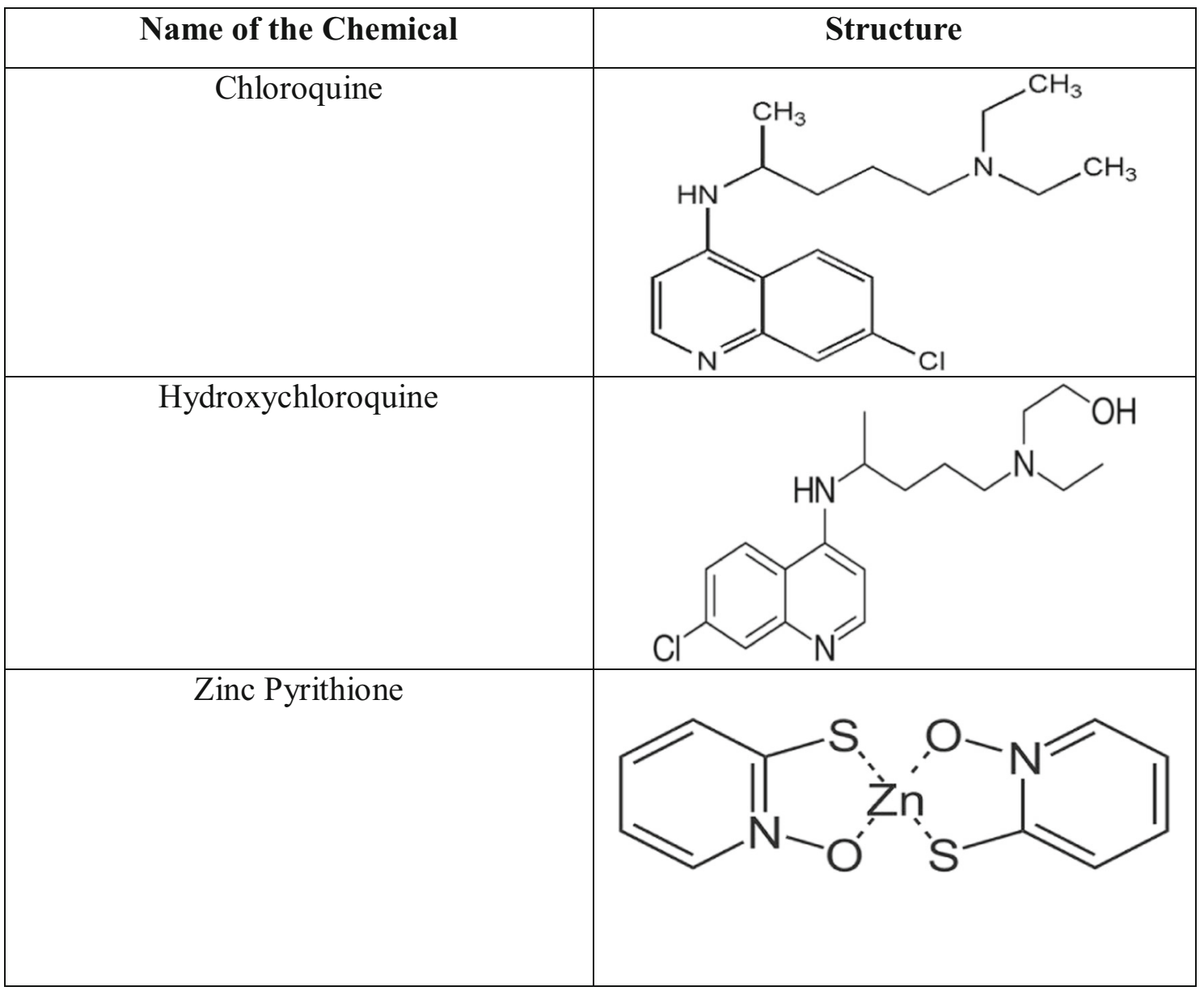

skin, poor appetite, mental lethargy, delayed wound healing, cell-mediated immune dysfunctions, and abnormal neurosensory changes [25]. Figure 3 summarizes major functions of $\mathrm{Zn}$ in human body.

Today when the world is under severe impact of COVID19 pandemic, $\mathrm{Zn}$ is of particular interest. It has direct antiviral effect as well as immunomodulatory effect [26]. Reports show impaired $\mathrm{Zn}$ levels in cases of diabetes, obesity, and cardiovascular diseases [27] (Olechnowicz J, 2018); and also in aging [28]. Decade earlier $\mathrm{Zn}$ was also found to prevent H1N1 influenza (swine flu) [29]. This time also there are many conjectures that $\mathrm{Zn}$ compounds may be used as an adjunct therapy to increase antiviral resistance in COVID-19 cases $[26,30,31]$.

\section{Zinc in Antiviral Immunity: Role of $\mathrm{Zn}$-Ionophores}

The word "ionophore" means "ion carrier." Ionophores are the compounds that form complexes with specific ions and facilitate their transport across cell membranes. An ionophore typically has a hydrophilic pocket (or hole) that forms a reversible binding site specific for a particular ion. The exterior surface of an ionophore is hydrophobic, allowing the complexed ion in its pocket to cross the hydrophobic membrane [32]. Table 1 gives structure of some important Zn-ionophores. Zn-ionophores like pyrithione (PT) have been known to inhibit replications in various RNA viruses, e.g., picornaviruses [33]. PT inhibits SARS coronavirus RNA polymerase (RNA-dependent RNA polymerase, RdRp) activity by decreasing its replication (Fig. 4) [34]. This suggest that $\mathrm{step} / \mathrm{s}$ of virus replication is/are affected by intracellular $\mathrm{Zn}^{2+}$ levels (Fig. 5). A combination of $\mathrm{Zn}^{2+}$ and $\mathrm{Zn}$-ionophore effectively inhibits nidovirus replication in cell culture [34]. $\mathrm{Zn}$ is also a second messenger for immune cells, and its intracellular status is directly altered by an extracellular stimulus and then intracellular $\mathrm{Zn}$ participates in signaling events [35]. Zn ions are involved in many different cellular processes and have been proven crucial for the proper folding and activity of various cellular enzymes and transcription factors. The phagocytosis, intracellular killing, and cytokine production are some of the processes which get affected in the state of $\mathrm{Zn}$ deficiency [11]. 
Fig. 4 Demonstration of positive impact of zinc influx in the cell

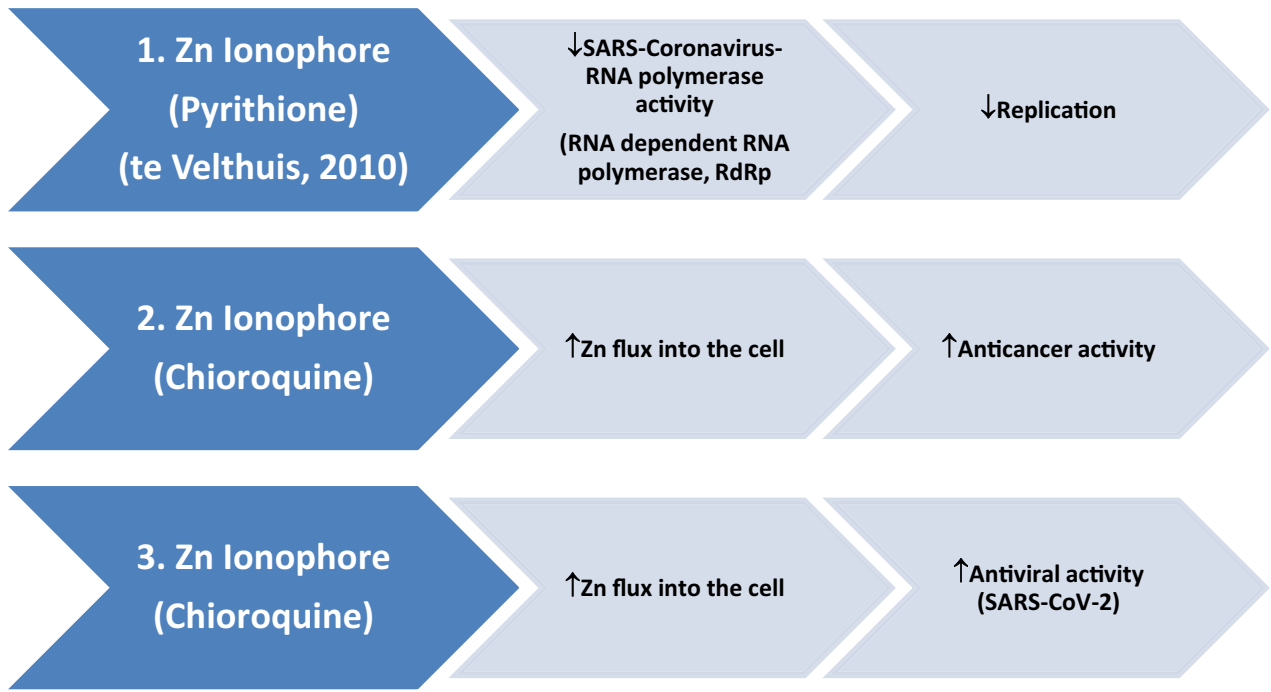

Another $\mathrm{Zn}$-ionophore is chloroquine (CQ) which is 4aminoquinoline, an antimalarial drug (Table 1) [36, 37]. Earlier findings demonstrated that CQ increased $\mathrm{Zn}^{2+}$ flux into the cell that is responsible for anticancer activity of the compound [38]. Based on these observations it is hypothesized that increasing intracellular $\mathrm{Zn}^{2+}$ concentration by chloroquine may also mediate its antiviral effect against SARS$\mathrm{CoV}-2$, for which trials were conducted and found to be effective (Fig. 4). CQ can transport ion ligands from extra cellular matrix into the cell in large amounts [39, 40]. CQ and its derivative hydroxychloroquine (HCQ) act as weak bases that can target key cellular signal transduction organelles such as lysosomes and Golgi [41, 42]. An increase in concentration of CQ in these organelles will catalyze significant disruption of downstream signaling processes via increase in the endosomal

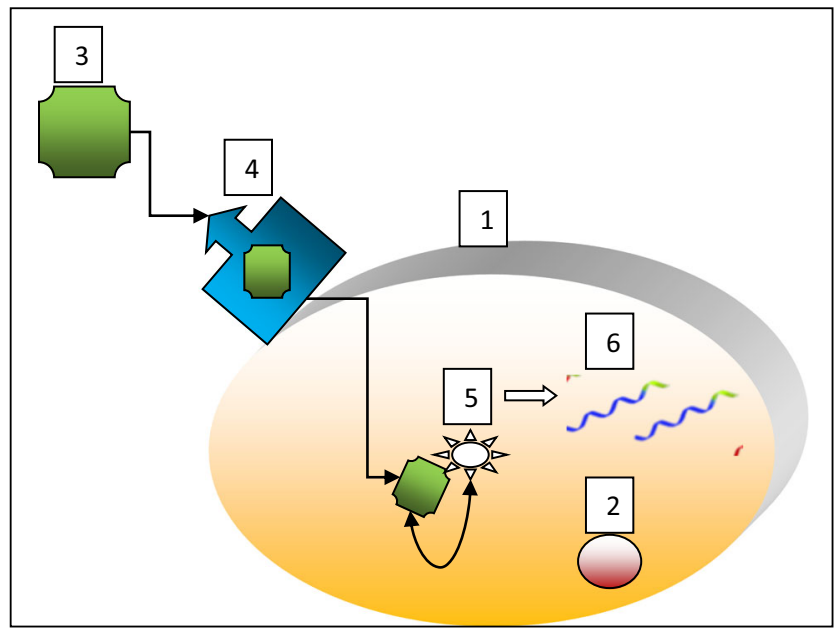

Fig. 5 Working of Zn-ionophores: (1) cell membrane; (2) cell cytoplasm; (3) Zn-ionophores (green) are extracellular; (4) cell membrane's importer molecules (blue) aid zinc to penetrate into the cell cytoplasm; (5) inside the cell, zinc is then able to block the enzyme RNA-dependent RNA polymerase of viral machinery (white); (6) viral replication stops and lysosomal $\mathrm{pH}$ [42]. $\mathrm{Zn}$ has been demonstrated to enhance chloroquine-induced apoptosis in A2780 cancer cell line. Zn along with CQ inhibited autophagy in the same cell line [38]. Based upon these observations Zn-ionophore CQ has been used to treat COVID-19 patients and is found to be potent to an extent.

\section{Targeting Zn lons in Proteins Present in Viral Structure}

The coronaviruses are enveloped positive-strand RNA viruses that replicate in the cytoplasm of infected cells [43] (Barretto, 2005). They have large RNA genomes ( 27 to $32 \mathrm{~kb}$ ), and viral replication is mediated by the viral RNA-dependent, RNA polymerase, termed the replicase [44].

The coronavirus replicase is initially translated from the $5^{\prime}$ terminal which makes up to $21 \mathrm{~kb}$ out of the total $29.7 \mathrm{~kb}$ of SARS-CoV genomic RNA to produce two replicase polyproteins, termed ppla and pplb. These polyproteins are processed by replicase-encoded proteases, PLpro (papain-like proteases), and 3CLpro (3C-like proteases), to generate 16 replicase products, termed non-structural proteins (nsp) 1 to 16. The coronavirus replicase intermediates and processing products assemble on intracellular membranes to generate double-membrane vesicles (DMVs), which are the site of viral RNA synthesis [45-47]. nsp14 of coronaviruses is important for viral replication and transcription. SARS-CoV complex comprises nsp14, nsp10 (activator), and functional ligands. Single molecule of nsp10 interacts with exon of nsp14 to stabilize it and stimulate its activity. The catalytic core of nsp14 exon is reminiscent of proofreading exonucleases; however there is presence of two $\mathrm{Zn}$ fingers that are essential for folding and functionality of nsp14 [48]. The presence of these two $\mathrm{Zn}$ fingers indicates that there is another approach to 
modulate COVID-19 by targeting $\mathrm{Zn}$ ions in the structure of viral proteins.

Drugs like disulfiram can bind to cysteine moieties of proteins present in virus [49]. Studies have indicated that disulfiram may inhibit or destabilize proteins present in the structure of virus by ejecting $\mathrm{Zn}$ from $\mathrm{Zn}$-bound cysteines. Disulfiram binds both to active site and also to Zn-binding sites in SARSCoV PLpro [50]. The studies on coronavirus structure revealed the presence of residual cysteine moieties in its envelop which plays role in virus biogenesis [51].

\section{Zn Levels: Influence of Age and Comorbidities}

Various case studies published on COVID-19 indicated that hospitalized subjects with old age are more prone to this disease. This may be due to the fact that comorbidities like hypertension, diabetes, cardiovascular disease, and cerebrovascular disease are more prevalent in old aged people [52]. Such people also have compromised immune system because of restricted diets and lesser amount of food intake. Sometimes due to medications appetite is reduced in elderly persons. As mentioned above in this review, $\mathrm{Zn}$ ions are indispensable for immune function. There is prevalence of $\mathrm{Zn}$ deficiency in hospitalized subjects and it is therefore justified that $\mathrm{Zn}$ supplementation to these subjects normalize $\mathrm{Zn}$ levels and ultimately restore their immune functions [40]. $\mathrm{Zn}$ is very essential for maintaining homeostasis as it is fundamental for biochemical reactions in our bodies. $\mathrm{Zn}$ is not stored in the body and hence required in daily dietary intake. The levels of $\mathrm{Zn}$ can be maintained in the body through regulated intestinal uptake followed by fecal excretion and renal reabsorption. Zn deficiency is frequently found in elderly patients, more often in those who have underlying conditions of respiratory infections, cardiac failure and atherosclerosis [53]. Elderly people tend to avoid high cholesterol diets like meat etc. that are rich source of $\mathrm{Zn}$. They consume refined wheat products and hence gradually their body becomes $\mathrm{Zn}$ deficient and become susceptible to various ailments $[54,55]$. It has been demonstrated that the level of $\mathrm{Zn}$ was low in whole blood and scalp hair of diabetic patients; moreover the severity is higher in older age group (61-75 Years). Further with advancement of age, the absorption of $\mathrm{Zn}$ also becomes low in the gut [56]. $\mathrm{Zn}$ is responsible for synthesis, storage, secretion, and conformational integrity of insulin monomers. Thus, lower levels of Zn may affect the ability of pancreatic islet cells to produce insulin [57]. Decreased plasma and intracellular Zn concentrations is in concurrence with increased urinary $\mathrm{Zn}$ excretion in diabetic patients. In subjects with type 2 diabetes mellitus with low $\mathrm{Zn}$ intake, the risk of coronary heart disease increases by a factor of two to four times and is a major cause of mortality among diabetic patients [56].
In addition it has been found that with advancement of age as the $\mathrm{Zn}$ level goes down, there is deregulation of immune functions that may further lead to age-related infections, inflammation and morbidities [58]. Studies indicate that in old age, methylation of specific zinc transporters may take place resulting in zinc transporter deregulation further leading to age-related Zn deficiency and inflammation. Reduced ZIP6 mRNA expression, enhanced proinflammatory responses and age-specific ZIP6 deregulation correlated with an increase in ZIP6 promoter methylation. However, dietary supplementation of $\mathrm{Zn}$ reduced aged-associated inflammation [58].

\section{Mechanism of COVID-19 Infections: Role of Zinc in Cardiorespiratory Function}

There is remarkable similarity between RNA sequence of SARS-CoV and SARS-CoV-2 [59]. In 2005 the mechanism of infection by SARS-CoV has already been identified in details [60]. It has been held that both these viruses follow same mechanism and this has led to an enhancement and application of knowledge to study SARS-CoV-2. Mainly lungs get infected by SARS-CoV virus [60]. Angiotensinconverting enzyme (ACE) 2 present in lungs, mainly in lung endothelium, vascular epithelial cells, and alveolar cells (pneumocytes - type II), acts as receptor for the virus [61]. Both SARS-CoV and SARS-CoV-2 use their spike proteins of the envelope to infect mammalian cells. These spike proteins share $76.5 \%$ homology in the amino acid sequence and thus almost identical 3-D structure to bind to the ACE-2 receptors of the spike (S) protein of the envelope that both viruses use to infect mammalian cells. But SARS-CoV-2 has higher affinity than SARS-CoV for receptors and this may account for its increased virulence [60]. SARS-CoV and SARS-CoV-2 binds with ACE-2 activate transmembrane serine protease-2 (TMPRSS2) and get entry into the cells. This activation of TMPRSS2 may be responsible for fatal conditions of COVID-9 [62, 63]. In addition ACE also forms an important component of renin-angiotensin system (RAS). RAS plays role in pathogenesis of essential hypertension and its complications. Hypertension may also be caused due to endothelial dysfunction. Thus, RAS modulation and ACEinhibitors play crucial role in the treatment of hypertension. ACE converts angiotensin I to angiotensin II (vasoconstrictor). Angiotensin II degrades bradykinin (a vasodilator) and maintains vascular tone and cardiac functions [64]. ACE is a Zinc metallopeptidase that means Zinc is essential for the catalytic activity of this enzyme. The enzyme contains one g-atom of zinc per mole of protein $[65,66]$. Thus, $\mathrm{Zn}$ plays significant role in cardiac function and finds its potential role in preventing viral infections as well. 


\section{Perspectives and Conclusions}

Till date, there is no effective medicine or vaccine for COVID19. Worldwide, almost 8 lakhs people have lost their life till date. In such scenario, the target is to save human life. The strategy should concentrate upon boosting immune system and repurposing of old drugs to control the viral replication. $\mathrm{Zn}$ is identified as one of the most essential trace element to fulfill this interesting proposition. Zinc is known to enhance antiviral potential in mammalian cells. Different approaches are there in which this trace element could prove useful in fighting life-threatening infections. Zinc makes structural component of numerous enzymes in the cell thus zinc supplementation may help in treatment and prophylaxis of COVID19 like it did in the case of SARS-CoV.

\section{Compliance with Ethical Standards}

Conflict of Interest The authors declare that they have no conflict of interest.

\section{References}

1. Tay MZ, Poh CM, Rénia L, MacAry PA, Ng LF (2020) The trinity of COVID-19: immunity, inflammation and intervention. Nat Rev Immunol 20:363-374. https://doi.org/10.1038/s41577-020-0311-8

2. Kumar A, Kubota Y, Chernov M, Kasuya H (2020) Potential role of zinc supplementation in prophylaxis and treatment of COVID19. Med Hypotheses 144:109848. https://doi.org/10.1016/j.mehy. 2020.109848

3. Hui DS, Memish ZA, Zumla A (2014) Severe acute respiratory syndrome vs. the Middle East respiratory syndrome. Curr Opin Pulm Med 20:233-241. https://doi.org/10.1097/MCP. 0000000000000046

4. Su S, Wong G, Shi W, Liu J, Lai ACK, Zhou J, Liu W, Bi Y, Gao GF (2016) Epidemiology, genetic recombination, and pathogenesis of coronaviruses. Trends Microbiol 24:490-502. https://doi.org/10. 1016/j.tim.2016.03.003

5. Zhu N, Zhang D, Wang W, Li X, Yang B, Song J, Zhao X, Huang B, Shi W, Lu R, Niu P, Zhan F, Ma X, Wang D, Xu W, Wu G, Gao GF, Tan W, China Novel Coronavirus Investigating and Research Team (2020) A novel coronavirus from patients with pneumonia in China, 2019. N Engl J Med 382:727-733. https://doi.org/10.1056/ NEJMoa2001017

6. Shulzhenko N, Morgun A, Hsiao W et al (2011) Crosstalk between B lymphocytes, microbiota and the intestinal epithelium governs immunity versus metabolism in the gut. Nat Med 17:1585-1593. https://doi.org/10.1038/nm.2505

7. Nielsen FH (2012) History of zinc in agriculture. Adv Nutr 3:783789. https://doi.org/10.3945/an.112.002881

8. Prasad AS, Halsted JA, Nadimi M (1961) Syndrome of iron deficiency anemia, hepatosplenomegaly, hypogonadism, dwarfism and geophagia. Am J Med 31:532-546. https://doi.org/10.1016/00029343(61)90137-1

9. Prasad AS (2009) Zinc: role in immunity, oxidative stress and chronic inflammation. Curr Opin Clin Nutr Metab Care 12:646652. https://doi.org/10.1097/MCO.0b013e3283312956

10. Filippini T, Cilloni S, Malavolti M, Violi F, Malagoli C, Tesauro M, Bottecchi I, Ferrari A, Vescovi L, Vinceti M (2018) Dietary intake of cadmium, chromium, copper, manganese, selenium and zinc in a Northern Italy community. J Trace Elem Med Biol 50: 508-517. https://doi.org/10.1016/j.jtemb.2018.03.001

11. Sharma L (2020) Dietary management to build adaptive immunity against COVID-19. J PeerSci 2:e1000016. https://doi.org/10.5281/ zenodo. 3774086

12. Kambe T, Hashimoto A, Fujimoto S (2014) Current understanding of ZIP and ZnT zinc transporters in human health and diseases. Cell Mol Life Sci 71:3281-3295. https://doi.org/10.1007/s00018-0141617-0

13. Jackson MA, Slininger PJ, Bothast RJ (1989) Effects of zinc, iron, cobalt and manganese on fusarium moniliforme nrrl 13616 growth and fusarin c biosynthesis in submerged cultures. Appl Environ Microbiol 55:649-655. https://doi.org/10.1128/AEM.55.3.649655.1989

14. King JC, Shames DM, Woodhouse LR (2000) Zinc homeostasis in humans. J Nutr 130:1360-1366. https://doi.org/10.1093/jn/130.5. $1360 \mathrm{~S}$

15. To Phuong K, Do MH, Cho JH, Jung C (2020) Growth modulatory role of zinc in prostate cancer and application to cancer therapeutics. Int J Mol Sci 21:2991. https://doi.org/10.3390/ijms21082991

16. Hara T, Takeda TA, Takagishi T, Fukue K, Kambe T, Fukada T (2017) Physiological roles of zinc transporters: molecular and genetic importance in zinc homeostasis. J Physiol Sci 67:283-301. https://doi.org/10.1007/s12576-017-0521-4

17. Lambert SA, Jolma A, Campitelli LF, Das PK, Yin Y, Albu M, Chen X, Taipale J, Hughes TR, Weirauch MT (2018) The human transcription factors. Cell 172:650-665. https://doi.org/10.1016/j. cell.2018.01.029

18. Andreini C, Bertini I (2012) A bioinformatics view of zinc enzymes. J Inorg Biochem 111:150-156. https://doi.org/10.1016/j. jinorgbio.2011.11.020

19. Overbeck S, Rink L, Haase H (2008) Modulating the immune response by oral zinc supplementation: a single approach for multiple diseases. Arch Immunol Ther Exp (Warsz) 56:15-30. https://doi. org/10.1007/s00005-008-0003-8

20. Kumssa DB, Joy EJ, Ander EL, Watts MJ, Young SD, Walker S, Broadley MR (2015) Dietary calcium and zinc deficiency risks are decreasing but remain prevalent. Sci Rep 5:10974. https://doi.org/ 10.1038/srep10974

21. Wessells KR, Brown KH (2012) Estimating the global prevalence of zinc deficiency: results based on zinc availability in national food supplies and the prevalence of stunting. PLoS One 7(11):e50568. https://doi.org/10.1371/journal.pone.0050568

22. Himoto T, Masaki T (2018) Associations between zinc deficiency and metabolic abnormalities in patients with chronic liver disease. Nutrients 10:88. https://doi.org/10.3390/nu10010088

23. Siva S, Rubin DT, Gulotta G, Wroblewski K, Pekow J (2017) Zinc deficiency is associated with poor clinical outcomes in patients with inflammatory bowel disease. Inflamm Bowel Dis 23:152-157. https://doi.org/10.1097/MIB.0000000000000989

24. Shankar AH, Prasad AS (1998) Zinc and immune function: the biological basis of altered resistance to infection. Am J Clin Nutr 68:447-463. https://doi.org/10.1093/ajcn/68.2.447S

25. Prasad AS (2013) Discovery of human zinc deficiency: its impact on human health and disease. Adv Nutr 4:176-190. https://doi.org/ 10.3945/an.112.003210

26. Skalny AV, Rink L, Ajsuvakova OP, Aschner M, Gritsenko VA, Alekseenko SI, Svistunov AA, Petrakis D, Spandidos DA, Aaseth J, Tsatsakis A (2020) Zinc and respiratory tract infections: perspectives for COVID-19. Int J Mol Med 46:17-26. https://doi.org/10. 3892/ijmm.2020.4575

27. Olechnowicz J, Tinkov A, Skalny A, Suliburska J (2018) Zinc status is associated with inflammation, oxidative stress, lipid, and glucose metabolism. J Physiol Sci 68:19-31. https://doi.org/10. 1007/s12576-017-0571-7 
28. Haase H, Overbeck S, Rink L (2008) Zinc supplementation for the treatment or prevention of disease: current status and future perspectives. Exp Gerontol 43:394-408. https://doi.org/10.1016/j. exger.2007.12.002

29. Sandstead HH, Prasad AS (2010) Zinc intake and resistance to H1N1 influenza. Am J Public Health 100:970-971. https://doi. org/10.2105/AJPH.2009.187773

30. Read SA, Obeid S, Ahlenstiel C, Ahlenstiel G (2019) The role of zinc in antiviral immunity. Adv Nutr 10:696-710. https://doi.org/ 10.1093/advances/nmz013

31. Zhang L, Liu Y (2020) Potential interventions for novel coronavirusin China: a systematic review. J Med Virol 92:479490. https://doi.org/10.1002/jmv. 25707

32. Freedman JC (2012) Ionophores in planar lipid bilayers. In: Nicholas S (ed) Cell Physiology Source Book, 4th edn. Academic Press Elsevier, Cambridge

33. Krenn BM, Gaudernak E, Holzer B, Lanke K, Van Kuppeveld FJM et al (2009) Antiviral Activity of the Zinc Ionophores Pyrithione and Hinokitiol against Picornavirus Infections. J Virol 83:58-64. https://doi.org/10.1128/JVI.01543-08

34. Te Velthuis AJ, van den Worm SH, Sims AC, Baric RS, Snijder EJ, van Hemert MJ (2010) Zn2+ inhibits coronavirus and arterivirus RNA polymerase activity in vitro and zinc ionophores block the replication of these viruses in cell culture. PLoS Pathog 6: e1001176. https://doi.org/10.1371/journal.ppat.1001176

35. Hojyo S, Fukada T (2016) Roles of zinc signaling in the immune system. J Immunol Res 21. https://doi.org/10.1155/2016/6762343

36. Goldberg SB, Supko JG, Neal JW et al (2012) A phase I study of erlotinib and hydroxychloroquine in advanced non- small-cell lung cancer. J Thorac Oncol 7:1602-1608. https://doi.org/10.1097/JTO. 0b013e318262de4a

37. Yu H, Zhou Y, Lind SE, Ding WQ (2009) Clioquinol tar gets zinc to lysosomes in human cancer cells. Biochem J 417:133-139. https://doi.org/10.1042/BJ20081421

38. Xue J, Moyer A, Peng B, Wu J, Hannafon BN, Ding WQ (2014) Chloroquine is a zinc ionophore. PLoS One 9:e109180. https://doi. org/10.1371/journal.pone.0109180

39. Haase H, Rink L (2009) The immune system and the impact of zinc during aging. Immun Ageing 6:9. https://doi.org/10.1186/17424933-6-9

40. Lind SE, Park JS, Drexler JW (2009) Pyrithione and 8hydroxyquinolinestransport lead across erythrocyte membranes. Am J Transl Res 154:153-159. https://doi.org/10.1016/j.trsl. 2009.06.002

41. Li M, Khambu B, Zhang H et al (2013) Suppression of lysosome function induces autophagy via a feedback down-regulation of MTOR complex 1 (MTORC1) activity. J Biol Chem 288:3576935780. https://doi.org/10.1074/jbc.M113.511212

42. Mauthe M, Orhon I, Rocchi C et al (2018) Chloroquine inhibits autophagic flux by decreasing autophagosome- lysosome fusion. Autophagy 14:1435-1455. https://doi.org/10.1080/15548627. 2018.1474314

43. Barretto N, Jukneliene D, Ratia K, Chen Z, Mesecar AD, Baker SC (2005) The papain-like protease of severe acute respiratory syndrome coronavirus has deubiquitinating activity. J Virol 79: 15189-15198. https://doi.org/10.1128/jvi.79.24.15189-15198. 2005

44. Ziebuhr J (2005) The coronavirus replicase. Curr Top Microbiol Immunol 287:57-94. https://doi.org/10.1007/3-540-26765-4_3

45. Goldsmith CS, Tatti KM, Ksiazek TG, Rollin PE, Comer JA, Lee WW, Rota PA, Bankamp B, Bellini WJ, Zaki SR (2004) Ultrastructural characterization of SARS coronavirus. Emerg Infect Dis 10:320-326. https://doi.org/10.3201/eid1002.030913

46. Gosert R, Kanjanahaluethai A, Egger D, Bienz K, Baker SC (2002) RNA replication of mouse hepatitis virus takes place at double- membrane vesicles. J Virol 76:3697-3708. https://doi.org/10. 1128/JVI.76.8.3697-3708.2002

47. Prentice E, Jerome WG, Yoshimori T, Mizushima N, Denison MR (2004) Coronavirus replication complex formation utilizes components of cellular autophagy. J Biol Chem 279:10136-10141. https:// doi.org/10.1074/jbc.M306124200

48. Ma Y, Wu L, Shaw N, Gao Y, Wang J, Sun Y, Lou Z, Yan L, Zhang R, Rao Z (2015) Structural basis and functional analysis of the SARS coronavirus nsp14-nsp10 complex. Proc Natl Acad Sci 112:9436-9441. https://doi.org/10.1073/pnas.1508686112

49. Scozzafava A, Casini A, Supuran CT (2002) Targeting cysteine residues of biomolecules: new approaches for the design of antiviral and anticancer drugs. Curr Med Chem 19:1167-1185. https://doi. org/10.2174/0929867023370077

50. Lin MH, Moses DC, Hsieh CH, Cheng SC, Chen YH, Sun CY, Chou CY (2018) Disulfiram can inhibit MERS and SARS coronavirus papain-like proteases via different modes. Antivir Res 150: 155-163. https://doi.org/10.1016/j.antiviral.2017.12.015

51. Lopez LA, Riffle AJ, Pike SL, Gardner D, Hogue BG (2008) Importance of conserved cysteine residues in the coronavirus envelope protein. J Virol 82:3000-3010. https://doi.org/10.1128/JVI. 01914-07

52. Garnier-Crussard A, Forestier E, Gilbert T, Krolak-Salmon P (2020) Novel coronavirus (COVID-19) epidemic: what are the risks for older patients? J Am Geriatr Soc 68:939-940. https://doi. org/10.1111/jgs. 16407

53. Vasto S, Mocchegiani E, Candore G, Listì F, Colonna-Romano G, Lio D, Malavolta M, Giacconi R, Cipriano C, Caruso C (2006) Inflammation, genes and zinc in ageing and age-related diseases. Biogerontology 7:315-327. https://doi.org/10.1007/s10522-0069046-6

54. Cunningham-Rundles S, McNeeley DF, Moon A (2005) Mechanisms of nutrient modulation of the immune response. $\mathrm{J}$ Allergy Clin Immunol 115:1119-1128. https://doi.org/10.1007/ s10522-006-9046-6

55. Webb P, Nishida C, Darnton-Hill I (2007) Age and gender as factors in the distribution of global micronutrient deficiencies. Nutr Rev 65:233-245. https://doi.org/10.1111/j.1753-4887.2007. tb00300.x

56. Kazi TG, Afridi HI, Kazi N, Jamali MK, Arain MB, Jalbani N, Kandhro GA (2008) Copper, chromium, manganese, iron, nickel, and zinc levels in biological samples of diabetes mellitus patients. Biol Trace Elem Res 122:1-8. https://doi.org/10.1007/s12011-0078062-y

57. DiSilvestro RA (2000) Zinc in relation to diabetes and oxidative disease. J Nutr 130:1509S-1511S. https://doi.org/10.1093/jn/130. 5.1509S

58. Wong CP, Magnusson KR, Ho E (2013) Increased inflammatory response in aged mice is associated with age-related zinc deficiency and zinc transporter dysregulation. J Nutr Biochem 24:353-359. $\mathrm{https} / / /$ doi.org/10.1016/j.jnutbio.2012.07.005

59. Zhou P, Yang X, Wang X et al (2020) A pneumonia outbreak associated with a new coronavirus of probable bat origin. Nature 579:270-273. https://doi.org/10.1038/s41586-020-2012-7

60. Kuba K, Imai Y, Penninger JM (2006) Angiotensin-converting enzyme 2 in lung diseases. Curr Opin Pharmacol 6:271-276. https:// doi.org/10.1016/j.coph.2006.03.001

61. Rossi GP, Sanga V, Barton M (2020) Potential harmful effects of discontinuing ACE-inhibitors and ARBs in COVID-19 patients. Elife 9:e57278. https://doi.org/10.7554/eLife.57278

62. Heurich A, Hofmann-Winkler H, Gierer S, Liepold T, Jahn O, Pöhlmann S (2014) TMPRSS2 and ADAM17 cleave ACE2 differentially and only proteolysis by TMPRSS2 augments entry driven by the severe acute respiratory syndrome coronavirus spike protein. J Virol 88:1293-1307. https://doi.org/10.1128/JVI.02202-13 
63. Hoffmann M, Kleine-Weber H, Schroeder S, Krüger N, Herrler T, Erichsen S, Schiergens TS, Herrler G, Wu NH, Nitsche A, Müller MA (2020) SARS-CoV-2 cell entry depends on ACE2 and TMPRSS 2 and is blocked by a clinically proven protease inhibitor. Cell 181:271-281. https://doi.org/10.1016/j.cell.2020.02.052

64. Ekmekci OB, Donma O, Tunckale A (2003) Angiotensinconverting enzyme and metals in untreated essential hypertension. Biol Trace Elem Res 95:203-210. https://doi.org/10.1385/BTER: 95:3:203

65. Bünning P, Riordan JF (1985) The functional role of zinc in angiotensin converting enzyme: implications for the enzyme mechanism.
J Inorg Biochem 24:183-198. https://doi.org/10.1016/01620134(85)85002-9

66. Spyroulias GA, Galanis AS, Pairas G, Manessi-Zoupa E, Cordopatis P (2004) Structural features of angiotensin-I converting enzyme catalytic sites: conformational studies in solution, homology models and comparison with other zinc metallopeptidases. Curr Top Med Chem 4:403-429. https://doi.org/10.2174/ 1568026043451294

Publisher's Note Springer Nature remains neutral with regard to jurisdictional claims in published maps and institutional affiliations. 